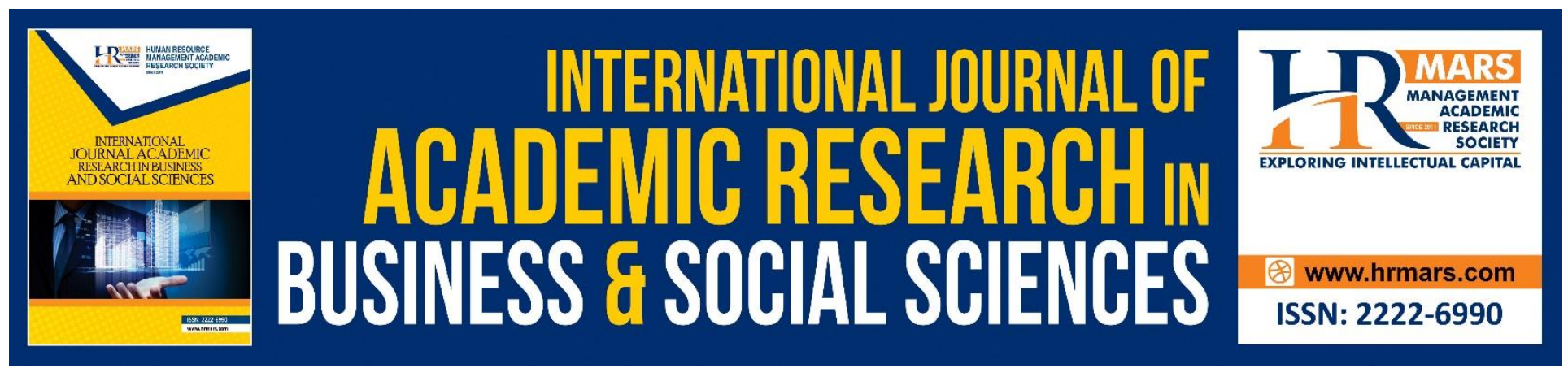

\title{
Selection a New Mobile Phone by Utilize the Voting Method, AHP and Enhance TOPSIS
}

Abdulhadi Qays Abdulhadi

To Link this Article: http://dx.doi.org/10.6007/IJARBSS/v10-i8/7621

DOI:10.6007/IJARBSS/v10-i8/7621

Received: 09 May 2020, Revised: 04 June 2020, Accepted: 20 July 2020

Published Online: 16 August 2020

In-Text Citation: (Abdulhadi, 2020)

To Cite this Article: Abdulhadi, A. Q. (2020). Selection a New Mobile Phone by Utilize the Voting Method, AHP and Enhance TOPSIS. International Journal Academic Research in Business and Social Sciences. 10(8), 717732.

Copyright: (C) 2020 The Author(s)

Published by Human Resource Management Academic Research Society (www.hrmars.com)

This article is published under the Creative Commons Attribution (CC BY 4.0) license. Anyone may reproduce, distribute, translate and create derivative works of this article (for both commercial and non-commercial purposes), subject to full attribution to the original publication and authors. The full terms of this license may be seen at: $\underline{\text { http://creativecommons.org/licences/by/4.0/legalcode }}$

Vol. 10, No. 8, 2020, Pg. 717 - 732

http://hrmars.com/index.php/pages/detail/IJARBSS

JOURNAL HOMEPAGE

Full Terms \& Conditions of access and use can be found at http://hrmars.com/index.php/pages/detail/publication-ethics 


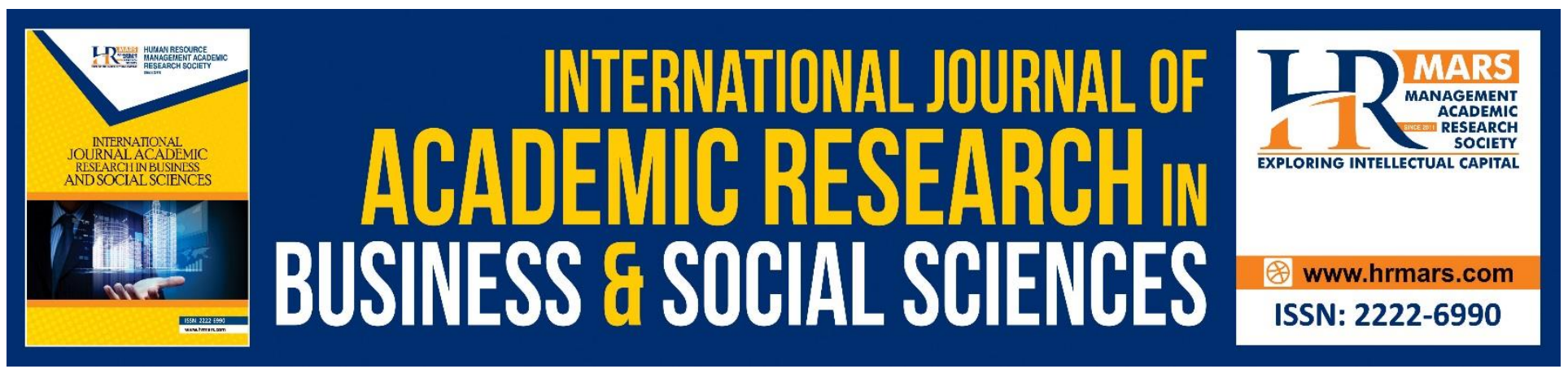

\title{
Selection a New Mobile Phone by Utilize the Voting Method, AHP and Enhance TOPSIS
}

\author{
Abdulhadi Qays Abdulhadi \\ Faculty Art and Scientific Computing/ University Pendidikan Sultan Idris \\ Email: Phdhadi2016@gmail.com
}

\begin{abstract}
The most important expansions in the arenas of information technology and communication are mobile phones. Many brands of mobile phones existing in the market that make the decision of buying a new mobile phone a very difficult choice. The objective of this study is to estimate the mobile phone selections regarding human preferences (Customer) by utilizing the multi-criteria decision making (MCDM) methods. The most necessary criteria prefer and effect on the selection of decisionmakers are determined by utilized voting method while the voters are presented the perspectives of the 25 student's from UPSI (Sultan Idris Education University). Additional, AHP ( analytical hierarchy process) is used to define the weights of assessment criteria then the enhance TOPSIS (Techniques for order preference by similarity to an ideal solution) is utilized to rank the mobile phone alternatives.
\end{abstract}

Keywords: TOPSIS, AHP, MCDM, Mobile Phone, Weighted Euclidean Distance, Voting Method.

\section{Introduction}

Mobile phones have given away of rapid evolution by way of the generations promote which could determine the most important developments in the information technology and communication (Van Biljon, Kotzé, \& Renaud, 2008). Also, the overall mobile phone's determination continues to grow, motivate in the prosperity of mobile communication. Many companies have presented the different models of mobile phones respectively which have extra in a diversity of design, characteristics, Microprocessor, and others. Also, the prices are diverse among mobile phone model reliant on the aspect of each.

The mobile package market consumes substantial chances for development that make the mobile companies increase their competitiveness through improving mobile phone performance software operator and hardware aspect need to match customer request. Therefore, companies must comprehend the necessities of mobile phone facility customers (Shieh, Chang, Fu, Lin, \& Chen, 2014). Moreover, through technology development, most of the new mobile phones might consume the greatest of the top devices. In the direction of stability among several features besides a limited budget, customers might essential to study several features instead of the figure besides dimensions though selecting the correct phone to buy. companies' developer needs to determine and consider 
INTERNATIONAL JOURNAL OF ACADEMIC RESEARCH IN BUSINESS AND SOCIAL SCIENCES Vol. 10, No. 8, 2020, E-ISSN: 2222-6990 @ 2020 HRMARS

the subject of the importance of the aspect of mobile phones and presentation theirs after succeeding the new version of mobile phones(Jackson et al., 2008). The main fragment of the mobile phone is associated with the literature quintessence on the contented aspect. Also, the researcher has inspected the design characteristics of mobile phones with the perspective of consumer satisfaction (Ma, Zheng, Zhang, \& Zhou, 2016). Also, the usability of the mobile phone application to recommend tourism interesting to visit favorite places in Malang City (Dewi, Mentari, Saputro, Nugroho, \& Hibatullah, 2019). Moreover, the literature survey scholar tried to explore the association among user favorites of mobile phones besides design prerequisites as shown in table (1).

Table 1 literature survey

\begin{tabular}{ll}
\hline Research area & References \\
\hline $\begin{array}{l}\text { Mobile phone distribution besides their influences on persons everyday } \\
\text { lives }\end{array}$ & (Funk, 2005) \\
Mobile phone possession and utilized & $\begin{array}{l}\text { (Davie, Panting, } \\
\& \quad \text { Charlton, } \\
\text { 2004) } \\
\text { (Wilska, 2003) }\end{array}$ \\
$\begin{array}{l}\text { Mobile phone possession and utilize from a social besides mental } \\
\text { viewpoint }\end{array}$ & $\begin{array}{l}\text { (Weinberger \& } \\
\text { influences on people healthiness besides everyday events }\end{array}$ \\
$\begin{array}{l}\text { Assessment and strategy of mobile phone aspect and user } \\
\text { satisfaction of mobile phone }\end{array}$ & $\begin{array}{l}\text { (Lee, Hong, } \\
\text { Smith-Jackson, }\end{array}$ \\
$\begin{array}{l}\text { The connection among the feature favorites and their relationship } \\
\text { between purchaser satisfaction. }\end{array}$ & $\begin{array}{l}\text { Tomioka, 2006) } \\
\text { (Haverila, 2011) }\end{array}$ \\
\hline
\end{tabular}

Among these studies, selecting the best fitting mobile phones for customers to buy a new one could be considered as a complex multi-criteria decision (MCDM) problem (Alaa et al., 2019). The different environment that utilized MCDM methods as the mean key to solving problems which comprehends a numeral of decision alternatives and choice criteria (Abdulhadi, 2019; Qader et al., 2017). The MCDM is to locate the most eligible alternative(s) among a set of alternatives with the chosen criteria. MCDM methods can settle different issues in a wide domain like supply chain problem (Fasanghari, Kamalabadi, \& Mirzaei, 2008), sustainable development perspective (Hsu, Ou, \& Ou, 2015), construction project bidding risk assessment (Guo-feng \& Li-wen, 2010). Assessment of IPR initiates financing risk (Bao, Qu, Dong, Wang, \& Sheng, 2015), credit risk evaluation (Wu, Kou, \& Peng, 2012), E-Commerce Website (Wang, 2009), Network Selection in Wireless Networks (Lahby, Cherkaoui, \& Adib, 2013), Identifying influential nodes in complex networks (Hu, Du, Mo, Wei, \& Deng, 2016), Network Interface Selection in Heterogeneous Wireless Networks (Senouci, Hoceini, \& Mellouk, 2016). Mobile network interface selection (Senouci, Mushtaq, Hoceini, \& Mellouk, 2016). While researchers have explored the scheme around human resource performance or satisfaction appraisal and judgment assessment, Evaluating Human Resource Competitiveness (Hao, Zhao, Liu, \& Zhao, 2016), Expert judgment assessment, and ranking for Sports Team Formation (Dadelo, Turskis, 
INTERNATIONAL JOURNAL OF ACADEMIC RESEARCH IN BUSINESS AND SOCIAL SCIENCES Vol. 10, No. 8, 2020, E-ISSN: 2222-6990 @ 2020 HRMARS

Zavadskas, \& Dadeliene, 2014). the management perspectives for the desirable bancassurance alliance construction (Wu, Lin, \& Lin, 2009). Customer Satisfaction (Wu \& Zhu, 2011).

On the other hand, MCDM methods comprehend decision maker (DM) decisions and personal preferences, counting qualitative and/or quantitative criteria evaluations, also the weights of criteria. Nevertheless, these subjects' decisions can be inaccurate, unspecified, and ambiguous, creation of the decision-making procedure difficult after practical in the direction of real-world problems.

In general, the MCDM methods are separated into two lines, the first line considers the human decision in process for example Analytic Hierarchy Process (AHP). The second line is considering mathematical operations for example TOPSIS. It comes as no wonder that the earliest and most research works on TOPSIS development that aimed to solve the MCDM problems, it denotes to making decisions in the existence of the various inconsistent attribute. Many scholars have tried to hybrid TOPSIS with another method like AHP-TOPSIS (Hanine, Boutkhoum, Tikniouine, \& Agouti, 2016; Işıklar \& Büyüközkan, 2007; Mohamed, Leghris, \& Abdellah, 2011), or using AHP with modifying TOPSIS then compare the result with another algorithm such as Simple Additive Weighting (SAW) Method, Weighted Product Method (WPM), TOPSIS Method, Preference Ranking Organization Method for Enrichment Evaluations (PROMETHEE) and Grey Relational Analysis (GRA) utilized to valeted the rank (Gangurde \& Akarte, 2010). While some articles have proposed to comprehend the weight AHP and information Entropy weight method with TOPSIS (Chu \& Su, 2012; Sheng-mei, Su, \& Ming-hai, 2010). Moreover, (Kaabi \& Jabeur, 2015) utilized TOPSIS with the Variable Neighborhood Search (VNS) for produced objective weights continuous besides utilized AHP subjective weights are created (Wang, Zhu, \& Wang, 2016) This article combining the TOPSIS, GRA, and SAW methods. Voting methods are a type of group DM method that considers aggregating the preferences of individual decision-makers to group preferences; voting methods include a plurality, majority method (instant runoff or two-round runoff), pairwise comparison (Condorcet paradox or Copeland method) and Borda rank (Pérez-Fernández et al., 2016). He \& Jung, (2018) utilized a voting method (i.e. pairwise comparison) with a group of experts to determine the priority of criteria and applied it with TOPSIS to solve real problems in disaster-damaged areas. The weight for group decision-makers is calculated to achieve a committee consensus. (Ouenniche, Pérez-Gladish, \& Bouslah, 2018) used a voting method to classify the criteria of alternatives depending on the preferences of decisionmakers, and the criteria that were selected must have the majority of the voting.

Mobile phone selection problem in this day is considered as MCDM problem because of conflict criteria and the number of criteria increasing with time of developing a new mobile phone. So that this paper aims to consider the most and important criteria that decision maker needs when he wants to buy a new mobile phone among different alternatives.

- The criteria of this study are selected by using a voting method among different criteria and the most desirable is selected.

- The voters are presented the perspectives of the 25 students' from UPSI (Sultan Idris Education University).

- Expert are determined the alternatives of the requirement of marketing from different product of the mobile phone.

- The decision matrix is used by one customer to buy a new mobile phone.

- AHP is utilized to obtain the weights of criteria from personal decisions.

- Enhance TOPSIS is used for obtain the final rank. TOPSIS has enhanced by used Max normalization technique. Also, the weight is considered for the Euclidean distance that 
INTERNATIONAL JOURNAL OF ACADEMIC RESEARCH IN BUSINESS AND SOCIAL SCIENCES

Vol. 10, No. 8, 2020, E-ISSN: 2222-6990 @ 2020 HRMARS

measuring the distance between alternatives and the positive and negative ideal solution to obtain reasonable rank.

the rest of the paper is organized as follows: The methodology of this study is presented in Section 2. Section 3 is presenting the evaluating of mobile phone selection and discussions. Section 7 , is presenting the conclusion and the future work.

\section{Methodology}

The main objective of this study is to choose the most preferable mobile phone alternative between a numeral of alternatives (choices) regarding customer preferences. The assessment process of this study contains three major phases as brief in Figure (1).

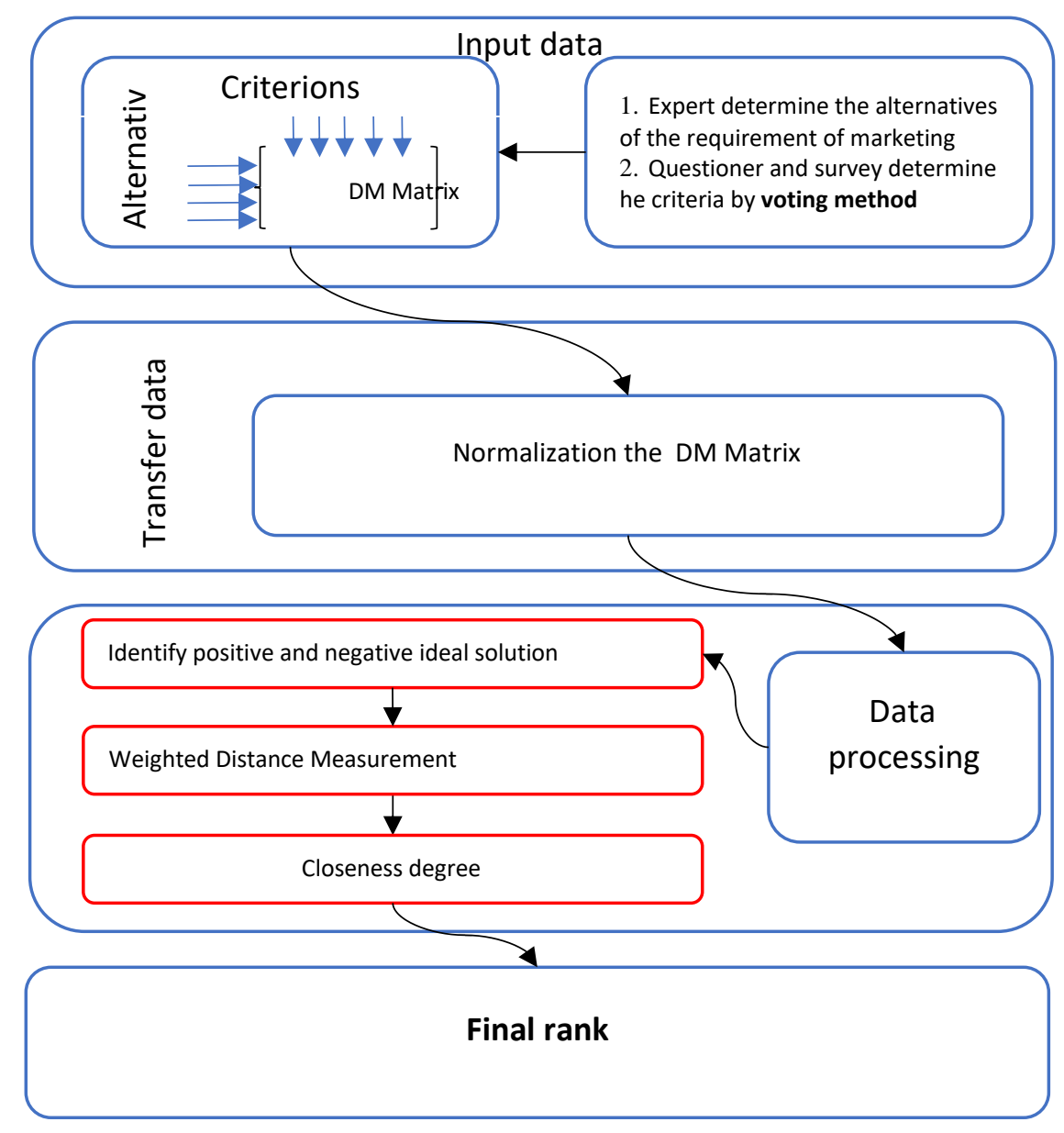

Figure 1. Methodology Process

Moreover, the most interesting of the mobile phone criteria that conducted to the questioner and between customers and the marketing experts to determine the criteria and the alternative by utilizing the voting method. 
INTERNATIONAL JOURNAL OF ACADEMIC RESEARCH IN BUSINESS AND SOCIAL SCIENCES Vol. 10, No. 8, 2020, E-ISSN: 2222-6990 @ 2020 HRMARS

All these criteria were recently collected depending on the company's announcement about the mobile phone aspect which directed us to propose the most reasonable criteria list to be useful in the questionnaire.

For the next step the questionnaire, Table 2, has been considered to voting and judge criteria depending on the preferences of the respondents when selecting a mobile phone.

Consequently, we suggest a voting method for selecting the most preferable criteria for a hybrid AHP method and enhance TOPSIS by used weighted- Euclidean distance. The steps of the methodology as fallow:

Step 1. Classifying the mobile phone alternatives and assessment criteria.

Step 2. Next, determine the weights of each criterion by AHP

Step 3. Determine the final rank by enhancing TOPSIS

Table 2 voting questionnaire

\begin{tabular}{|l|l|lll}
\hline No. & $\begin{array}{l}\text { Which criteria do you deliberate } \\
\text { when buying a new mobile } \\
\text { phone? }\end{array}$ & $\begin{array}{l}\text { Not imp } \\
\text { at all, }\end{array}$ \\
\hline 1. & Brand & Qut Very
\end{tabular}


INTERNATIONAL JOURNAL OF ACADEMIC RESEARCH IN BUSINESS AND SOCIAL SCIENCES Vol. 10, No. 8, 2020, E-ISSN: 2222-6990 @ 2020 HRMARS

The guidance of the marketing experts takes a meaningfully respected to select suitable alternatives. The students at the age of 23-28 years, who are included in additional as decision-makers of our university ( Sultan Idris Education University), this survey has received by email. They were asked to show their preferences to each of the criteria containing "very important ", "quite important ", "important", "not very important" and "not important at all" that is the linguistic impersonation of scale between 1 to 5 numeric respectively. A person's answer was aggregated by utilizing the geometric mean of each questionnaire. After, finish gathering all the requirements of the research and completed the questioner phase. Table 3 is showing customer criteria and product criteria which are the important criteria for DM (customer) to buy a new mobile. The product criteria consist of the sub-criteria which are basic requirements involving the reasonable cost/price, the standard part used, and the Microprocessor. The physical characteristics of the mobile including design standards the raw material properties, attractiveness water resistance, shape, dimension, solidity, or weight. While the technical features including safety standards, international roaming and talk and standby time. Moreover, customer criteria are including the functionality (the ease of use), the brand selection linking to the marketing.

while, the customer excitement is counting the Features adaptability, business-life facilitating services, and games.

\section{Analytical Hierarchy Process (AHP)}

AHP is developed by Thomas L. Saaty (Saaty, 1990) as the MCDM method for solve MCDM problems which involve human preferences in the process of comparison. AHP depends on the decisions of decision-makers to decompose a difficult problematic into a hierarchy through the aim by the highest level of the hierarchy. The criteria of the sub-level of the hierarchy, and choose alternatives at the bottom level of the hierarchy.

The AHP procedure is as follows.

Step 1: each criterion is compared as the pairwise comparison with others to create a decision matrix $(n * n)$, and the number of comparisons is $n(n-1) / 2$. The value of comparison to represent the importance of the criteria is scaled from 1 to 9 , as shown in Table (4).

Table 4 the linguistic meanings of comparison

\begin{tabular}{ll}
\hline Numerical assessment & Linguistic meaning \\
\hline 1 & Equal important \\
3 & Moderately more important \\
5 & Strongly more important \\
7 & Very strongly important \\
9 & Extremely more important \\
$2,4,6,8$ & Intermediate values of importance \\
\hline
\end{tabular}

Step 2: The decision matrix $(n * n)$, as shown as follows:

$$
A=\left(\begin{array}{ccccc}
x_{11} & x_{12} & \ldots & \ldots & x_{1 n} \\
x_{21} & x_{22} & \ldots & \ldots & x_{2 n} \\
\vdots & \vdots & \vdots & \ddots & \vdots \\
x_{n 1} & x_{n 2} & \ldots & \ldots & x_{n n}
\end{array}\right) \text { where, }\left\{\begin{array}{l}
x_{i i}=1 \\
x_{j i}=\frac{1}{x_{i j}}
\end{array}\right.
$$

Step 3: Normalize decision matrix by Equation (2). 
INTERNATIONAL JOURNAL OF ACADEMIC RESEARCH IN BUSINESS AND SOCIAL SCIENCES

Vol. 10, No. 8, 2020, E-ISSN: 2222-6990 @ 2020 HRMARS

$$
a_{i j}=\frac{x_{i j}}{\sum_{i=1}^{n} x_{i j}}
$$

This procedure trimmings after a normalized matrix $\left(A_{\text {norm }} . A_{\text {norm }}\right), A_{\text {norm }}(a i j)$ is obtained, such that

$$
A_{n o r m}=\left(\begin{array}{ccccc}
a_{11} & a_{12} & \ldots & \ldots & a_{1 n} \\
a_{21} & a_{22} & \ldots & \ldots & a_{2 n} \\
\vdots & \vdots & \vdots & \ddots & \vdots \\
a_{n 1} & a_{n 2} & \ldots & \ldots & a_{n n}
\end{array}\right)
$$

Step 4: The weight of each criterion is determined from the matrix $A_{\text {norm }}$ by

$$
W_{i}=\frac{\sum_{j=1}^{n} a_{i j}}{n} \text { and } \sum_{j=1}^{n} W_{i}=1
$$

Where $\mathrm{n}$ is the number of criteria, and the sum of weights is equal to one.

Step 5: In this step, the Consistency Ratio (CR) in DM is determined. The CR is considered from $\mathrm{Cl}$ measures, and the mark of inconsistency is intended by Equation (2.5). RI is the compliant mark of the inconsistency, RI that is calculated by Equation (2.6).

$$
C I=\frac{\lambda \max -n}{n-1}
$$

$R I=$

$\frac{1.98(n-1)}{n} . C I$

The $C R$ is defined in Equation (2.7) as follows:

$$
C R=
$$

$\frac{C I}{R I}$

The CR should be less than $10 \%$, or 0.1 is acceptable. If the level of inconsistency is unacceptable, then the decision-maker should revise the pairwise comparisons; otherwise, it will be ignored.

\section{TOPSIS}

TOPSIS is proposed by Hwang and Yoon in 1981 [10], which is constructed on selecting the best alternative mast farthest from the negative-ideal solution and closer to the ideal solution. The main process of TOPSIS is determined by the distance which figuring among individually alternative from the positive and negative ideal solution. The nearest alternative to the positive solution and farthest from the negative solution be the higher rank. TOPSIS technique has been processed in the following steps:

Step 1: Normalized decision matrix, a conversion of the values of the matrix $\left(\mathrm{x}_{\mathrm{ij}}\right)_{\mathrm{m} * \mathrm{n}}$ into nondimensional matrix $\left(\mathrm{x}_{\mathrm{ij}}\right)_{\mathrm{m} * \mathrm{n}}$ value, in equation (8).

$$
r_{i j}=x_{i j} / \max _{i} x_{i j}
$$

Matrix $\mathbf{R}$ (normalized decision matrix) is shown as below: 
INTERNATIONAL JOURNAL OF ACADEMIC RESEARCH IN BUSINESS AND SOCIAL SCIENCES

Vol. 10, No. 8, 2020, E-ISSN: 2222-6990 @ 2020 HRMARS

$$
R=\left[\begin{array}{cccc}
r_{11} & r_{12} & \ldots & r_{1 n} \\
r_{21} & r_{22} & \ldots & r_{2 n} \\
\vdots & \vdots & \vdots & \vdots \\
r_{m 1} & r_{m 2} & \ldots & r_{m n}
\end{array}\right]
$$

Step 3: the positive ideal $A^{*}$ and negative ideal $A^{-}$solutions are measured as in the below:

$$
\begin{gathered}
A^{*}=\left\{\left(\left(\max _{i} r_{i j} \mid j \in J\right),\left(\min _{i} r_{i j} \mid j \in J^{-}\right) \mid i=1,2, \ldots, m\right)\right\} \\
=\left\{r_{1}^{*}, r_{2}^{*}, \ldots, r_{j}^{*}, \cdots r_{n}^{*}\right\} \\
A^{-}=\left\{\left(\left(\min _{i} r_{i j} \mid j \in J\right),\left(\max _{i} r_{i j} \mid j \in J^{-}\right) \mid i=1,2, \ldots, m\right)\right\} \\
=\left\{r_{1}^{-}, r_{2}^{-}, \ldots, r_{j}^{-}, \cdots r_{n}^{-}\right\}
\end{gathered}
$$

Step 4: the weighted Euclidean distance. this process is measuring the distance among the alternative to the ideal solution by equation (3-21).

$$
S_{i^{*}}=\sqrt{\sum_{j=1}^{n} w_{j}\left(r_{i j}-r_{j}^{*}\right)^{2}}, i=(1,2, \cdots m) \quad \ldots
$$

Similarly, measuring the distance between the alternative to the negative ideal is given by:

$$
S_{i^{-}}=\sqrt{\sum_{j=1}^{n} w_{j}\left(r_{i j}-r_{j}^{-}\right)^{2}}, i=(1,2, \cdots m)
$$

Step 5: Closeness to the ideal solution calculation is defined as:

$C_{i^{*}}=S_{i^{-}} /\left(S_{i^{-}}+S_{i^{*}}\right), \quad 0<C_{i^{*}}<1, i=(1,2, \cdots m)$

Step 6: Ranking the alternative according to the closeness to the ideal solution.

\section{Evaluating Mobile Phone Selection and Discussions}

The mobile selection problem has been repeated because of the development of a new feature of mobile phone (smartphone) and different brands in the marketing. So that we have depending on the survey and preferences of customers buy a new mobile phone. Consequently, considering the demand for mobile phone access among young people, by applying the voting method (plurality method), that is utilized to express the preferences of the 25 students from UPSI which have participants as voters to meet customer satisfaction. After receiving the questionnaire from the voters and determine the most plurality criteria by taking 4 or 5 scores considered how many voted does each criterion has got which will determine as a winner. Moreover, the winner criteria are brand, price, storage space, camera, Dimensions, LCD Resolution, Ram, microprocessor, and battery size when which consider as the most preferable criteria to buy a new smartphone. While the alternatives have been selected by a marketing expert to give the requirement of the marketing as shown in table (4). Moreover, someone how wants to buy a new mobile phone and he confuses between the choice's alternatives and criteria the best way to help him by utilized MCDM methods. AHP has utilized to present the priority of the decision-maker regarding each criterion to obtain the weights and check the inconsistency as shown in figure (2). While enhance TOPSIS has utilized to rank the alternative and presented the best choices to the buyer. Furthermore, the decision matrix has some criteria that could not normalize so that to solve this problem by asking the buyer utilized five Likert 
INTERNATIONAL JOURNAL OF ACADEMIC RESEARCH IN BUSINESS AND SOCIAL SCIENCES Vol. 10, No. 8, 2020, E-ISSN: 2222-6990 @ 2020 HRMARS

scales for describing the criteria that cannot normalized like (brand, camera, dimensions, LCD resolution, a microprocessor), and table (5) is presented the new decision matrix.

Table (4) decision matrix.

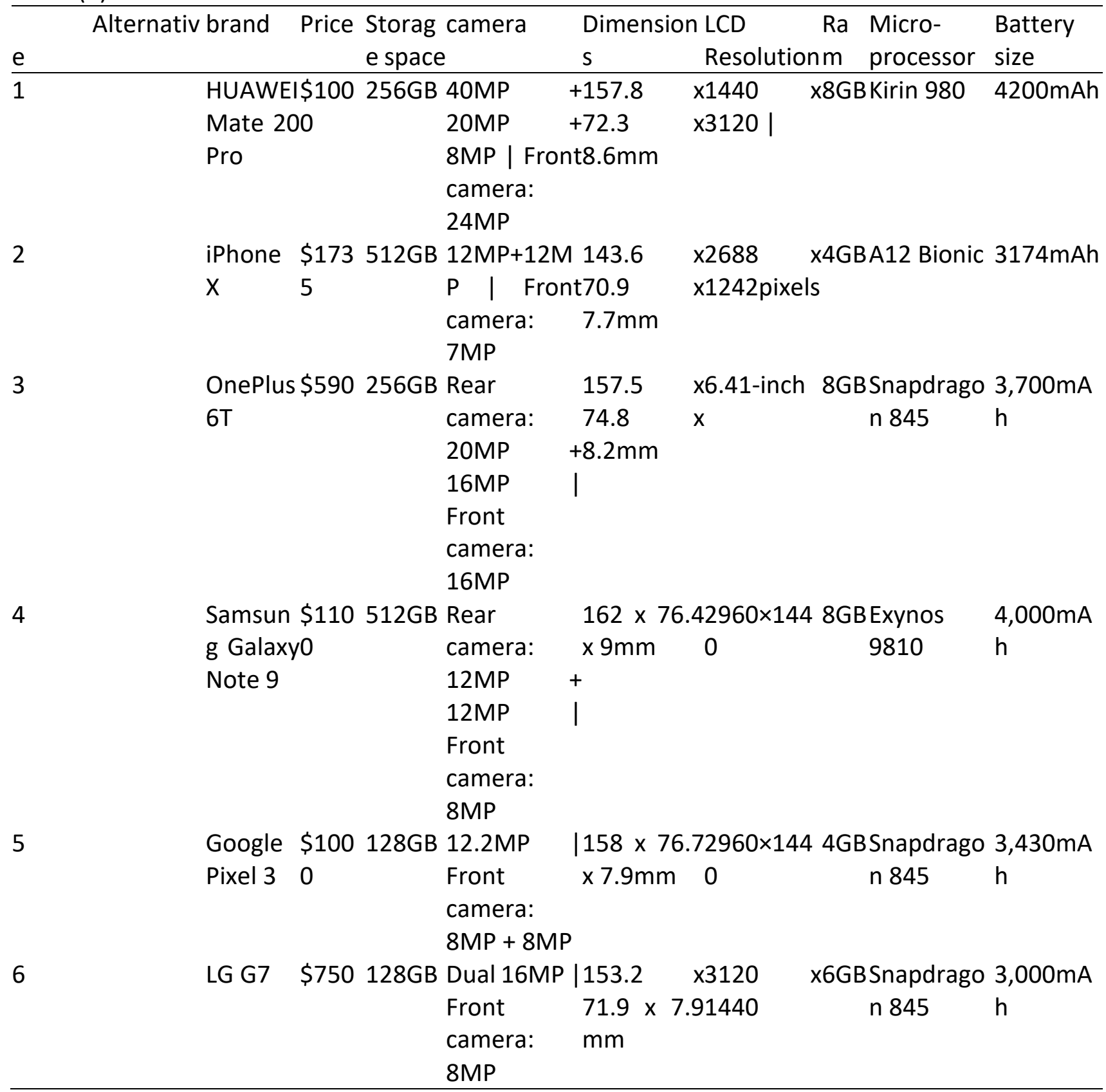


INTERNATIONAL JOURNAL OF ACADEMIC RESEARCH IN BUSINESS AND SOCIAL SCIENCES Vol. 10, No. 8, 2020, E-ISSN: 2222-6990 @ 2020 HRMARS

Table (5) the new decision matrix

\begin{tabular}{|c|c|c|c|c|c|c|c|c|c|}
\hline \multicolumn{2}{|c|}{ Alternativebrand } & Price & $\begin{array}{l}\text { Storage } \\
\text { space }\end{array}$ & camera & \multicolumn{2}{|c|}{ DimensionsLCD } & Ram & \multicolumn{2}{|c|}{$\begin{array}{l}\text { Micro- Battery } \\
\text { processor size }\end{array}$} \\
\hline 1 & 4 & $\$ 1000$ & $256 \mathrm{~GB}$ & 5 & 4 & 5 & $8 G B$ & 4 & $4200 \mathrm{mAh}$ \\
\hline 2 & 3 & $\$ 1735$ & $512 \mathrm{~GB}$ & 3 & 3 & 3 & $4 G B$ & 4 & $3174 \mathrm{mAh}$ \\
\hline 3 & 3 & $\$ 590$ & $256 \mathrm{~GB}$ & 4 & 4 & 3 & $8 \mathrm{~GB}$ & 5 & 3,700mAh \\
\hline 4 & 5 & $\$ 1100$ & $512 \mathrm{~GB}$ & 3 & 5 & 4 & $8 \mathrm{~GB}$ & 5 & 4,000mAh \\
\hline 5 & 3 & $\$ 1000$ & $128 \mathrm{~GB}$ & 3 & 4 & 4 & $4 G B$ & 5 & $3,430 \mathrm{mAh}$ \\
\hline 6 & 4 & $\$ 750$ & $128 \mathrm{~GB}$ & 3 & 4 & 5 & $6 G B$ & 5 & $3,000 \mathrm{mAh}$ \\
\hline
\end{tabular}

The new decision matrix is normalized by utilized equation (8) which divided each criterion on the maximum value of the column. The maximum normalization equation is better from used (Vector normalization, Linear normalization 1, Linear normalization 2) method will give a different result (Fu, Yang, \& Lu, 2007; Jahan, Bahraminasab, \& Edwards, 2012; Zaidan \& Zaidan, 2017). Table (6) is illustrated the normalized decision matrix and minimize the scale of values and unify the different dimension of criteria.

Table (6) the normalize matrix

\begin{tabular}{|c|c|c|c|c|c|c|c|c|c|}
\hline \multirow{2}{*}{\multicolumn{2}{|c|}{$\begin{array}{l}\text { Alternati brand } \\
\text { ve }\end{array}$}} & \multirow{2}{*}{ Price } & \multirow{2}{*}{$\begin{array}{l}\text { Storage } \\
\text { space }\end{array}$} & \multirow[t]{2}{*}{ camera } & \multicolumn{2}{|c|}{ Dimension LCD } & \multirow{2}{*}{ Ram } & \multirow{2}{*}{$\begin{array}{l}\text { Micro- } \\
\text { processor }\end{array}$} & \multirow{2}{*}{$\begin{array}{l}\text { Battery } \\
\text { size }\end{array}$} \\
\hline & & & & & s & $\begin{array}{l}\text { Res } \\
\text { on }\end{array}$ & & & \\
\hline 1 & 0.8 & $\begin{array}{l}0.576 \\
69\end{array}$ & 0.5 & 1 & 0.8 & 1 & 1 & 0.8 & 1 \\
\hline 2 & 0.6 & 1 & 1 & 0.6 & 0.6 & 0.6 & 0.5 & 0.8 & $\begin{array}{l}0.75571 \\
4\end{array}$ \\
\hline 3 & 0.6 & $\begin{array}{l}0.340 \\
58\end{array}$ & 0.5 & 0.8 & 0.8 & 0.6 & 1 & 1 & $\begin{array}{l}0.88095 \\
2\end{array}$ \\
\hline 4 & 1 & $\begin{array}{l}0.634 \\
06\end{array}$ & & 0.6 & 1 & 0.8 & 1 & 1 & $\begin{array}{l}0.95238 \\
1\end{array}$ \\
\hline 5 & 0.6 & $\begin{array}{l}0.576 \\
69\end{array}$ & 0.25 & 0.6 & 0.8 & 0.8 & 0.5 & 1 & $\begin{array}{l}0.81666 \\
7\end{array}$ \\
\hline 6 & 0.8 & $\begin{array}{l}0.432 \\
77\end{array}$ & 0.25 & 0.6 & 0.8 & 1 & 0.75 & 1 & $\begin{array}{l}0.71428 \\
6\end{array}$ \\
\hline
\end{tabular}




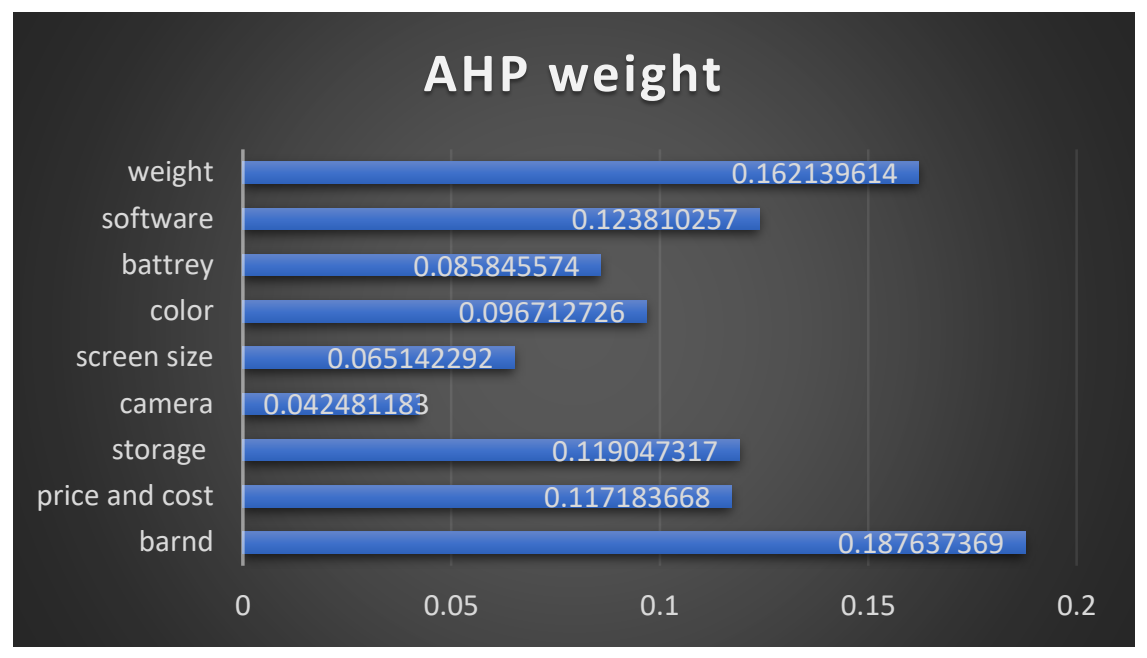

Figure (2) the priority of weight to each criterion

The positive ideal solution and the negative ideal solution is specifying by equation (10), (11). Additionally, the measure the distances of each alternative to the ideal solution $s_{i}^{*}$ and the ones to non-ideal solution $s_{i}^{-}$by applying weight Euclidean distance equation (12), (13) as shown in table (9). Finally, the last step of the TOPSIS involves ranking the alternatives regarding their comparative closeness $(\mathrm{Cl})$ to the ideal solution. In the end, HUAWEI Mate 20 Pro is the utmost wanted mobile phone between alternatives with the final performance value of 0.924457; although Samsung Galaxy Note 9 has placed at the second with score 0.724224 .

Table 9 The weighted Euclidean distance and relative closeness

\begin{tabular}{lrlll}
\hline Alternative & $s_{i}^{*}$ & \multicolumn{1}{c}{$s_{i}^{-}$} & $\mathrm{Cl}$ & Result - rank \\
\hline 1 & 0.080629 & 0.98671 & 0.924457 & 1 \\
2 & 0.917218 & 0.751143 & 0.450228 & 5 \\
3 & 0.714007 & 0.946468 & 0.569998 & 3 \\
4 & 0.451059 & 1.184543 & 0.724224 & 2 \\
5 & 1.045233 & 0.556727 & 0.347529 & 6 \\
6 & 0.952973 & 0.815359 & 0.461089 & 4 \\
\hline
\end{tabular}

\section{Conclusions}

The findings of this study are the decision matrix for selection mobile phone problem and the evaluation. The criteria have considered by the students at the age of 23-28 years which presented the maximum significant criteria in the selection of a mobile phone. Moreover, voting method is used for determine the criteria by gathering the votes of each candidate (criterion), While the alternatives have been selected by a marketing expert based on the requirement of marketing need. This approach varies from the investigations of the selection of mobile phone by previous researchers, since it identifies the best criteria for decision maker which consist of the psychology of customers. Moreover, the evaluation of the criteria weight reveals the importance placed on each criterion. The alternatives are presented with the greatest current mobile phone in 2018 in marketing. This investigative help to inspect the present mobile phone market overall besides select the most precise choice for buying a new smartphone. Moreover, this study including MCDM 
in the core of this problem. AHP has utilized to presented the perspective and priority of each criterion and determined the weight to utilized in the procedure of enhancing TOPSIS. The enhance is including to utilized different normalization techniques and proposed weighted Euclidean distance that presented the priority of the best solution regarding the closeness to the positive ideal solution and farthest from the negative ideal solution.

The Future direction, the results did not consist of the contribution of other mobile phone criteria like service operators, which could include in the consideration of criteria. Also, the mobile service manufacturing remains to raise and grow, beside the criteria disturbing the implementation of mobile services will variation continually. For example, Huawei has latest smartphones lacking various of the apps (YouTube, Google Maps and Gmail among other software) classically preinstalled on Android phones. Furthermore, the extraordinary acceptance of mobile phones in everyday life, struggle by the performance of several companies to fetch numerous categories of mobile phones with deference price and aspect to the market which need to considered in the procedure of selection operation is still open issues. Moreover, the proposed methodology of this study could be used more and different criteria with several alternatives of mobile phones. Also, societal and educational edges of mobile phone consumption remained discontinued; As an alternative to making the right choice for the consumer who is the reason for this study.

\section{References}

Abdulhadi, A. Q. (2019). Review of Hybrid TOPSIS with other Methods.

Alaa, M., Albakri, I. S. M. A., Singh, C. K. S., Hammed, H., Zaidan, A., Zaidan, B., . . Almahdi, E. (2019). Assessment and ranking framework for the English skills of pre-service teachers based on fuzzy Delphi and TOPSIS methods. IEEE access, 7, 126201-126223.

Bao, X., Qu, Q., Dong, Y., Wang, Y., \& Sheng, X. (2015). Risk evaluation of value assessment in IPR pledge financing based on interval value TOPSIS method. Paper presented at the Logistics, Informatics and Service Sciences (LISS), 2015 International Conference on.

Chu, J., \& Su, Y. (2012). The application of TOPSIS method in selecting fixed seismic shelter for evacuation in cities. Systems Engineering Procedia, 3, 391-397.

Dadelo, S., Turskis, Z., Zavadskas, E. K., \& Dadeliene, R. (2014). Multi-criteria assessment and ranking system of sport team formation based on objective-measured values of criteria set. Expert Systems with Applications, 41(14), 6106-6113.

Davie, R., Panting, C., \& Charlton, T. (2004). Mobile phone ownership and usage among preadolescents. Telematics and Informatics, 21(4), 359-373.

Dewi, R. K., Mentari, M., Saputro, W., Nugroho, U. A., \& Hibatullah, M. H. (2019). Usability Analysis of TOPSIS based Mobile Recommender System of Malang Tourism. Paper presented at the 2019 International Conference on Sustainable Information Engineering and Technology (SIET).

Fasanghari, M., Kamalabadi, I. N., \& Mirzaei, A. H. (2008). IT based supply chain agility evaluation using a new TOPSIS with interval data. Paper presented at the Convergence and Hybrid Information Technology, 2008. ICCIT'08. Third International Conference on.

Fu, C., Yang, S., \& Lu, W. (2007). An extended TOPSIS for belief group decision making. Paper presented at the Fuzzy Systems and Knowledge Discovery, 2007. FSKD 2007. Fourth International Conference on.

Funk, J. L. (2005). The future of the mobile phone Internet: an analysis of technological trajectories and lead users in the Japanese market. Technology in Society, 27(1), 69-83. 
INTERNATIONAL JOURNAL OF ACADEMIC RESEARCH IN BUSINESS AND SOCIAL SCIENCES Vol. 10, No. 8, 2020, E-ISSN: 2222-6990 @ 2020 HRMARS

Gangurde, S., \& Akarte, M. (2010). Ranking of product alternatives based on customer-designer preferences. Paper presented at the Industrial Engineering and Engineering Management (IEEM), 2010 IEEE International Conference on.

Guo-feng, W., \& Li-wen, C. (2010). Construction project bidding risk assessment model based on rough set-TOPSIS. Paper presented at the Information Engineering (ICIE), 2010 WASE International Conference on.

Hanine, M., Boutkhoum, O., Tikniouine, A., \& Agouti, T. (2016). Application of an integrated multicriteria decision making AHP-TOPSIS methodology for ETL software selection. SpringerPlus, 5(1), 1.

Hao, H., Zhao, S., Liu, Z., \& Zhao, F. (2016). Evaluating human resource competitiveness based on an improved TOPSIS method: The case of automotive industry. Paper presented at the Industrial Engineering and Engineering Management (IEEM), 2016 IEEE International Conference on.

Haverila, M. (2011). Mobile phone feature preferences, customer satisfaction and repurchase intent among male users. Australasian Marketing Journal (AMJ), 19(4), 238-246.

He, Y., \& Jung, H. (2018). A Voting TOPSIS Approach for Determining the Priorities of Areas Damaged in Disasters. Sustainability, 10(5), 1607.

Hsu, L.-C., Ou, S.-L., \& Ou, Y.-C. (2015). A Comprehensive performance evaluation and ranking methodology under a sustainable development perspective. Journal of Business Economics and Management, 16(1), 74-92.

Hu, J., Du, Y., Mo, H., Wei, D., \& Deng, Y. (2016). A modified weighted TOPSIS to identify influential nodes in complex networks. Physica A: Statistical Mechanics and its Applications, 444, 73-85.

Işıklar, G., \& Büyüközkan, G. (2007). Using a multi-criteria decision making approach to evaluate mobile phone alternatives. Computer Standards \& Interfaces, 29(2), 265-274.

Jackson, L. A., Zhao, Y., Kolenic III, A., Fitzgerald, H. E., Harold, R., \& Von Eye, A. (2008). Race, gender, and information technology use: The new digital divide. CyberPsychology \& Behavior, 11(4), 437-442.

Jahan, A., Bahraminasab, M., \& Edwards, K. (2012). A target-based normalization technique for materials selection. Materials \& Design, 35, 647-654.

Kaabi, H., \& Jabeur, K. (2015). TOPSIS using a mixed subjective-objective criteria weights for ABC inventory classification. Paper presented at the Intelligent Systems Design and Applications (ISDA), 2015 15th International Conference on.

Lahby, M., Cherkaoui, L., \& Adib, A. (2013). An enhanced-TOPSIS based network selection technique for next generation wireless networks. Paper presented at the Telecommunications (ICT), 2013 20th International Conference on.

Lee, Y. S., Hong, S. W., Smith-Jackson, T. L., Nussbaum, M. A., \& Tomioka, K. (2006). Systematic evaluation methodology for cell phone user interfaces. Interacting with Computers, 18(2), 304-325.

Ma, Q., Zheng, J., Zhang, S., \& Zhou, W. (2016). Feature evaluation for mobile phone changing based on large-scale user behavioral data. Paper presented at the 2016 8th International Conference on Wireless Communications \& Signal Processing (WCSP).

Mohamed, L., Leghris, C., \& Abdellah, A. (2011). A hybrid approach for network selection in heterogeneous multi-access environments. Paper presented at the New Technologies, Mobility and Security (NTMS), 2011 4th IFIP International Conference on. 
INTERNATIONAL JOURNAL OF ACADEMIC RESEARCH IN BUSINESS AND SOCIAL SCIENCES Vol. 10, No. 8, 2020, E-ISSN: 2222-6990 @ 2020 HRMARS

Ouenniche, J., Pérez-Gladish, B., \& Bouslah, K. (2018). An out-of-sample framework for TOPSIS-based classifiers with application in bankruptcy prediction. Technological Forecasting and Social Change, 131, 111-116.

Pérez-Fernández, R., Rademaker, M., Alonso, P., Díaz, I., Montes, S., \& De Baets, B. (2016). Representations of votes facilitating monotonicity-based ranking rules: From votrix to votex. International Journal of Approximate Reasoning, 73, 87-107.

Qader, M., Zaidan, B., Zaidan, A., Ali, S., Kamaluddin, M., \& Radzi, W. (2017). A methodology for football players selection problem based on multi-measurements criteria analysis. Measurement, 111, 38-50.

Saaty, T. L. (1990). How to make a decision: the analytic hierarchy process. European Journal of Operational Research, 48(1), 9-26.

Senouci, M. A., Hoceini, S., \& Mellouk, A. (2016). Utility function-based TOPSIS for network interface selection in heterogeneous wireless networks. Paper presented at the Communications (ICC), 2016 IEEE International Conference on.

Senouci, M. A., Mushtaq, M. S., Hoceini, S., \& Mellouk, A. (2016). TOPSIS-based dynamic approach for mobile network interface selection. Computer Networks.

Sheng-mei, L., Su, P., \& Ming-hai, X. (2010). An improved TOPSIS vertical handoff algorithm for heterogeneous wireless networks. Paper presented at the Communication Technology (ICCT), 2010 12th IEEE International Conference on.

Shieh, L.-F., Chang, T.-H., Fu, H.-P., Lin, S.-W., \& Chen, Y.-Y. (2014). Analyzing the factors that affect the adoption of mobile services in Taiwan. Technological Forecasting and Social Change, 87, 80-88.

Van Biljon, J., Kotzé, P., \& Renaud, K. (2008). Mobile phone usage of young adults: the impact of motivational factors. Paper presented at the Proceedings of the 20th Australasian Conference on Computer-Human Interaction: Designing for Habitus and Habitat.

Wang, P., Zhu, Z., \& Wang, Y. (2016). A novel hybrid MCDM model combining the SAW, TOPSIS and GRA methods based on experimental design. Information Sciences, 345, 27-45.

Wang, X. (2009). Comprehensive Evaluation on E-commerce Website Applying Improved TOPSIS Method. Paper presented at the Electronic Commerce and Business Intelligence, 2009. ECBI 2009. International Conference on.

Weinberger, Z., \& Richter, E. (2002). Cellular telephones and effects on the brain: the head as an antenna and brain tissue as a radio receiver. Medical Hypotheses, 59(6), 703-705.

Wilska, T. (2003). The role of m-services in the well-being of young people. Journal of Consumer Policy, 26(4), 441-463.

Wu, C.-R., Lin, C.-T., \& Lin, Y.-F. (2009). Selecting the preferable bancassurance alliance strategic by using expert group decision technique. Expert Systems with Applications, 36(2), 3623-3629.

Wu, W., Kou, G., \& Peng, Y. (2012). Credit risk evaluation by improved MCDM models. Paper presented at the Business Intelligence and Financial Engineering (BIFE), 2012 Fifth International Conference on.

Wu, Y.-L., \& Zhu, X.-Y. (2011). TOPSIS-based synthetic evaluation method for customer satisfaction. Paper presented at the Business Management and Electronic Information (BMEI), 2011 International Conference on. 
INTERNATIONAL JOURNAL OF ACADEMIC RESEARCH IN BUSINESS AND SOCIAL SCIENCES Vol. 10, No. 8, 2020, E-ISSN: 2222-6990 @ 2020 HRMARS

Zaidan, B., \& Zaidan, A. (2017). Comparative Study on the Evaluation and Benchmarking Information Hiding Approaches Based Multi-Measurement Analysis Using TOPSIS Method with Different Normalisation, Separation and Context Techniques. Measurement. 